\title{
PENGARUH CORPORATE SOCIAL RESPONSIBILITY (CSR) TERHADAP CORPORATE IMAGE DAN DAMPAKNYA PADA LOYALITAS PELANGGAN PT. PEGADAIAN (PERSERO) DI PULAU LOMBOK (KASUS PADA PENERIMA PROGRAM KEMITRAAN)
}

\section{Milana Prihatina D.T. ${ }^{\text {, }}$ Dwi Putra Buana Sakti ${ }^{2}$, Handry Sudiartha A. ${ }^{3}$}

${ }^{1}$ Faculty of Economics and Business, Mataram University, Indonesia.

E-mail : milanadirathome@gmail.com

2Faculty of Economics and Business, Mataram University, Indonesia.

${ }^{3}$ Faculty of Economics and Business, Mataram University, Indonesia.

\begin{tabular}{|c|c|}
\hline ARTICLE INFO & ABSTRACT \\
\hline $\begin{array}{l}\text { Keywords : } \\
\text { CSR ; Corporate Image ; Customer } \\
\text { Loyalty } \\
\text { How to cite: } \\
\text { Thome, Milana P D., Sakti, Dwi Putra } \\
\text { Buana., Athar, Handry Sudiartha (2018). } \\
\text { Pengaruh Corporate Social Responsibility } \\
\text { (CSR) Terhadap Corporate Image dan } \\
\text { Dampaknya Pada Loyalitas Pelanggan } \\
\text { PT. Pegadaian (Persero) di Pulau Lombok } \\
\text { (Kasus Pada Penerima Program } \\
\text { Kemitraan). JMM UNRAM, 7(2), } 60 \text { - } 71 \\
\text { DOI : } \\
\text { 10.29303/jmm.v7i2.318 }\end{array}$ & $\begin{array}{l}\text { This research is an associative study with a } \\
\text { quantitative approach. With } 89 \text { sample of customers of PT. } \\
\text { Pegadaian (Limited) which is obtained by cluster sampling } \\
\text { technique, consisting of customers which has received a } \\
\text { Partnership Program of CSR assistance in Lombok Island in } \\
\text { last } 3 \text { (three) years (2014-2016). This study used a causal } \\
\text { correlation, which have independent variables (influencing } \\
\text { variables) and dependent variables (variables that are affected). } \\
\text { This research aims to determine the causal correlation between } \\
\text { independent variables, CSR on the loyalty of customers of PT. } \\
\text { Pegadaian (Limited) on Lombok through the Corporate image } \\
\text { variable. } \\
\text { Based on the results of the research and discussion it is } \\
\text { inferred that : 1) There is a direct, positive and significant } \\
\text { influence between CSR variables on Corporate Image. The data } \\
\text { analysis showed that there is a very strong correlation between } \\
\text { CSR variables and Corporate Image. 2) There is a direct, } \\
\text { positive and significant influence between the variables of } \\
\text { Corporate Image on Customer Loyalty. The data analysis } \\
\text { showed that there is a very strong correlation between the } \\
\text { variables of Corporate Image on Customer Loyalty. 3) There is } \\
\text { a direct, positive and significant influence between CSR } \\
\text { variables on customer loyalty. The data analysis showed that } \\
\text { there is a very strong correlation between CSR variables on } \\
\text { customer loyalty. 4) There is a direct, positive and significant } \\
\text { influence between CSR variables on Customer Loyalty through }\end{array}$ \\
\hline
\end{tabular}




\section{NATIONALLY ACCREDITED JOURNAL - DECREE NO. 21/E/KPT/2018}

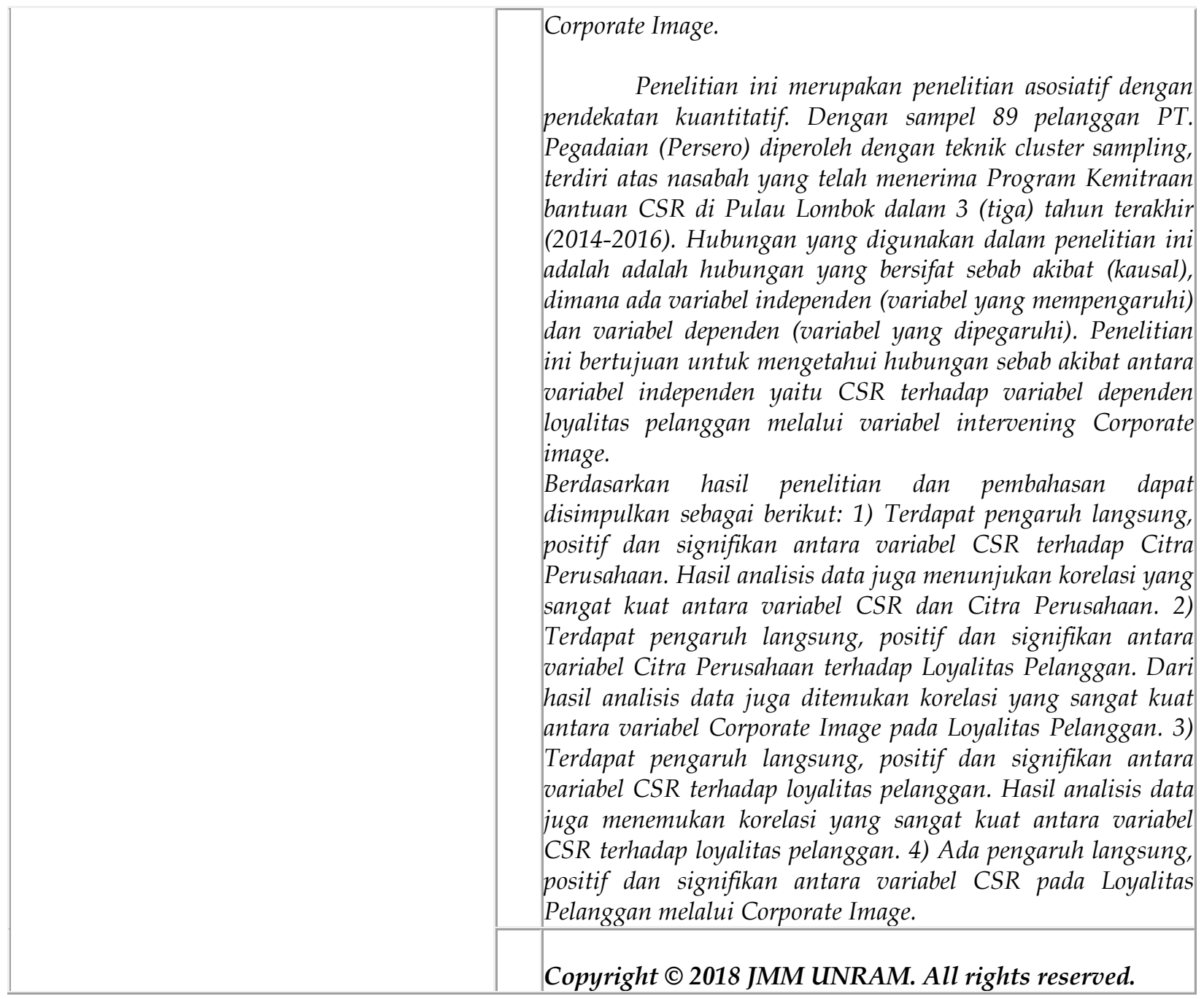

\section{PENDAHULUAN}

CSR adalah komitmen berkelanjutan kalangan bisnis untuk berperilaku etis dan memberikan sumbangan pada pembangunan ekonomi sekaligus memperbaiki mutu hidup angkatan kerja dan keluarganya serta komunitas lokal dan masyarakat secara keseluruhan (The World Business Council for Sustainable Development,1995). Pelaksanaan CSR di Indonesia, didukung oleh Undang- Undang Republik Indonesia Nomor 40 Tahun 2007 tentang Perseroan Terbatas Pasal 74 dan peraturan menteri BUMN no 4 Tahun 2007 tentang Program Kemitraan dan Bina Lingkungan (PKBL).

PT. Pegadaian telah melaksanakan program CSR melalui pembentukan unit PKBL \& CSR, dilaksanakan melalui kantor cabang yang tersebar di 5 kota/kabupaten yaitu Kota Mataram, Kabupaten Lombok Barat, Kabupaten Lombok Tengah, Kabupaten Lombok Timur dan Kabupaten Lombok Utara. Pelaksanaan CSR dengan benar mampu meningkatkan Corporate image (Kotler dan Lee, 2005). Dewasa ini perusahaan semakin menyadari dan menilai pelaksanaan CSR dapat dimanfaatkan sebagai sarana untuk dapat memenangkan persaingan dalam industri melalui pembentukan persepsi di benak konsumen sebagai perusahaan dengan image "citra" yang baik, peduli pada lingkungan dan masyarakat (Hurriyati \& Sofyani, 2010). 


\section{NATIONALLY ACCREDITED JOURNAL - DECREE NO. 21/E/KPT/2018}

Penerapan CSR akan dapat memberikan banyak keuntungan bagi perusahaan, salah satunya adalah mampu meningkatkan Corporate image (Yusdantara \& Rahanatha, 2015; Faroid \& Murtadlo, 2014).

Selain dapat meningkatkan citra perusahaan, CSR yang diterapkan secara tepat akan meningkatkan loyalitas pelanggan (Seravina, 2008). Kegiatan CSR dapat memberikan nilai tambah pada penilaian masyarakat sehingga menimbulkan kesetian pelanggan pada produk perusahaan, pengaruh CSR pada loyalitas pelanggan dipengaruhi oleh perilaku pembelian produk perusahaan secara berulang, hasil penelitian menunjukkan bahwa evaluasi total terhadap perusahaan dipengaruhi oleh evaluasi konsumen dengan adanya atribut produk perusahaan secara keseluruhan (Lois A. Mohr, Deborah J. Webb, And Katherme E. Harris, 2008).

Namun, implementasi CSR masih sering menunjukkan kecenderungan bahwa pelaksanaannya masih sebagai kegiatan kosmetik (Dwi Kartini, 2009). Dalam pelaksanaannya tidak semua CSR berdampak positif terhadap Corporate image, beberapa penelitian menemukan hal sebaliknya. Antara lain terungkap bahwa Sector CSR program kemitraan, pendidikan, kesehatan, pelestarian alam, bencana alam, olahraga seni dan budaya, sarana ibadah tidak berpengaruh signifikan terhadap citra perusahaan, bahkan sector sarana umum berpengaruh signifikan secara negative terhadap citra perusahaan (Yaskun dan Cahyono ,2016). Senada dengan itu bahwa penerapan CSR menghasilkan tanggapan yang kurang baik dari responden (Nirmalasari \& Ulum, 2014: Yaskun \& Cahyono, 2016).

Citra PT. Pegadaian dalam pandangan masyarakat saat ini cenderung "negative". Ketut Sethyon (2002) menyatakan bahwa pada umumnya masyarakat merasa malu datang ke pegadaian, keberadaan pegadaian sangat di butuhkan namun bayak di antara nasabah yang enggan berhubungan langsung/melakukan transakasi dengan pegadaian. PT. Pegadaian telah dan terus melaksakan program PKBL, namun tidak semua perusahaan melaksanakan CSR dengan baik (Nirmalasari dkk, 2014), sampai saat ini PT. Pegadaian (pesero) di Pulau Lombok belum memiliki alat pengukur performa pelaksanaan CSR ini.

Berdasarkan inkonsistensi hasil penelitian dalam mengukur pengaruh CSR terhadap Corporate image, sekaligus sebagai alat ukur performa CSR PT. Pegadaian (pesero) di Pulau Lombok yang berdampak pada loyalitas pelanggan, menjadi dasar pemikiran perlunya dilakukan penelitian dengan judul "Pengaruh Corporate Social Responsibilty (CSR) terhadap Corporate image dan dampaknya Padaloyalitas pelanggan PT. Pegadaian (Persero) di Pulau Lombok" (kasus pada penerima program kemitraan).

\section{TUJUAN PENELITIAN}

Tujuan dari penelitian ini adalah untuk membuktikan dan menganalisis :

1. Pengaruh CSR terhadap Corporate image PT. Pegadaian (pesero) di Pulau Lombok.

2. Pengaruh Corporate image terhadap Loyalitas pelanggan PT. Pegadaian (pesero) di Pulau Lombok.

3. Pengaruh secara langsung CSR terhadap Loyalitas pelanggan PT. Pegadaian (pesero) di Pulau Lombok.

4. Pengaruh CSR terhadap Loyalitas pelanggan PT. Pegadaian (pesero) di Pulau Lombok melalui variabel Corporate image. 


\section{NATIONALLY ACCREDITED JOURNAL - DECREE NO. 21/E/KPT/2018}

\section{KAJIAN KEPUSTAKAAN DAN HIPOTESIS}

\subsection{Definisi Corporate social responsibility (CSR)}

Di Indonesia, konsep CSR sebagaimana disebutkan dalam Undang-undang Nomor 40 Tahun 2007 tentang Perseroan Terbatas Pasal 1 ayat (3), “Tanggung Jawab Sosial dan Lingkungan adalah komitmen Perseroan untuk berperan serta dalam pembangunan ekonomi berkelanjutan guna meningkatkan kualitas kehidupan dan lingkungan yang bermanfaat, baik bagi Perseroan sendiri, komunitas setempat, maupun masyarakat pada umumnya".

Konsep corporate social responsibility (CSR) merupakan suatu pertimbangan perusahaan dalam aktivitas bisnisnya. Banhyak perusahaan telah menyadari bahwa pentingnya peran CSR dan harus dilakukan oleh perusahaan sebagai bentuk kepedulian terhadap para pemangku kepentingan (stakeholder).

\subsection{Indikator Pengukuran CSR}

Menurut Dwi Kartini (2009) ada 8 (delapan) indikator yang digunakan untuk mengukur implementasi CSR, yaitu :

1) Leadership (Kepemimpinan)

a. Program CSR dapat dikatakan berhasil jika mendapatkan dukungan dari top management perusahaan.

b. Terdapat kesadaran filantropik dari pimpinan yang menjadi dasar pelaksanaan program.

2) Proporsi Bantuan

CSR dirancang bukan semata-mata pada kisaran anggaran saja melainkan juga pada tingkatan serapan maksimal.

3) Transparansi dan Akuntabilitas

a. Terdapat laporan tahunan

4) Mempunyai mekanisme audit sosial dan financial

5) Cakupan Wilayah (Coverage Area)

Terdapat identifikasi penerima manfaat secara tertib dan rasional berdasarkan skala prioritas yang telah ditentukan.

6) Perencanaan dan Mekanisme Monitoring dan Evaluasi

a. Dalam perencanaan perlu ada jaminan untuk melibatkan mulit-stakeholder.

b. Terdapat kesadaran untuk memperhatikan aspek-aspek lokalitas (local wisdom)

c. Terdapat blue-print policy yang menjadi dasar pelaksanaan program.

7) Pelibatan Stakeholder (Stakeholder Enggagement)

a. Terdapat mekanisme koordinasi regular dengan stakeholders, utamanya masyarakat.

b. Terdapat mekanisme yang menjamin partisipasi masyarakat

8) Keberlanjutan (Sustainability)

a. Terjadi alih-peran dari korporat ke masyarakat

b. Tumbuhnya rasa memiliki (sense of belonging)

c. Adanya pilihan partner program yang bisa menjamin bahwa tanpa keikutsertaan perusahaan, program bias tetap dijalankan sampai selesai dengan partner tersebut.

9) Hasil Nyata (Outcome)

a. Terdapat dokumentasi hasil yang menunjukkan berkurangnya angka kesakitan dan kematian (dalam bidang kesehatan), atau parameter lainnya sesuai dengan bidang CSR yang dipilih perusahaan.

b. Terjadinya perubahan pola pikir masyarakat. 


\section{NATIONALLY ACCREDITED JOURNAL - DECREE NO. 21/E/KPT/2018}

c. Memberikan dampak ekonomi masyarakat yang dinamis.

d. Terjadi penguatan komunitas (community empowerment)

\subsection{Corporate image}

Menurut Philip Kotler, Citra adalah seperangkat keyakinan, ide dan kesan yang dimiliki seseorang terhadap suatu objek yang dibentuk dengan memproses informasi dari berbagai sumber setiap waktu (Kotler dan Keller, 2009). Pendapat Mackiewicz (dalam Oliver, 2007) menyebutkan bahwa : Citra perusahaan merupakan aset penting di era persaingan usaha saat ini. Hal ini penting dilakukan karena citra dapat mempengaruhi persepsi konsumen maupun publik.

\subsection{Indikator-Indikator Corporate image}

Upaya perusahaan sebagai sumber informasi terbentuknya citra perusahaan memerlukan keberadaan secara lengkap. Pemahaman yang berasal dari suatu informasi yang tidak lengkap menghasilkan citra yang tidak sempurna. Menurut Shirley Harrison (1995) dalam Yamada (2014) dan Chanafi (2009) Informasi yang lengkap mengenai citra perusahaan meliputi empat elemen sebagai berikut :

a) Corporate identity, komponen perusahaan yang mempermudah pengenalan publik sasaran terhadap perusahaan.

b) Reputasi, hal yang telah dilakukan perusahaan dan diyakini publik sasaran berdasarkan pengalaman sendiri maupun pihak lain seperti program CSR yang sesuai dengan kebutuhan masyarakat.

c) Value, nilai-nilai yang dimiliki suatu perusahaan

d) Personality, mencakup karakteristik perusahaan yang dipahami publik sasaran

\subsection{Pengertian Loyalitas pelanggan}

Secara harfiah loyal berarti setia, atau loyalitas dapat diartikan sebagai suatu kesetiaan. Istilah loyalitas sering kali diperdengarkan oleh pakar pemasaran maupun praktisi bisnis, loyalitas merupakan konsep yang tampak mudah dibicarakan dalam konteks sehari-hari, tetapi menjadi lebih sulit ketika dianalisis makananya. Perlu ditekankan bahwa hal tersebut berbeda dengan perilaku membeli ulang, loyalitas pelanggan menyertakan aspek perasaan, tidak melibatkan aspek afektif didalamnya (Dharmesta, dalam Diah Dharmayanti, 2006).

Loyalitas pelanggan merupakan salah satu tujuan inti yang diupayakan dalam pemasaran modern. Hal ini dikarenakan dengan loyalitas diharapkan perusahaan akan mendapatkan keuntungan jangka panjang atas hubungan mutualisme yang terjalindalam kurun waktu tertentu.

\subsection{Indikator Loyalitas}

Indikator dari loyalitas pelanggan menurut Kotler \& Keller (2006) adalah :

1. Repeat Purchase (kesetiaan terhadap pembelian produk)

2. Retention (ketahanan terhadap pengaruh yang negative terhadap perusahaan)

3. Referalls (mereferensikan secara total esistensi perusahaan)

\subsection{Hipotesis}

Dalam penelitian ini terdapat hubungan-hubungan yang menjelaskan keterkaitan antara masing-masing variabel : 


\section{NATIONALLY ACCREDITED JOURNAL - DECREE NO. 21/E/KPT/2018}

\subsubsection{Pengaruh CSR terhadap Corporate image}

Navickas V \& Kontautiene R (2011) menyatakan bahwa CSR akan memberikan berpengaruh positif terhadap performa ekonomi perusahaan,Corporate image dan loyalitas pelangan. Sehingga setiap praktik bisnis yang dibentuk dengan perencanaan yang baik dalam perwujudan tanggung jawab sosial akan memberikan persepsi yang baik bagi Corporate image (Hurryati \& Sofyani, 2010). Penelitian yang dilakukan Yusdantara dan Rahantha (2015) menyatakan bahwa CSR memiliki pengaruh positif dan signifikan terhadap reputasi perusahaan. Hasil penelitian yang sama juga ditunjukkan oleh hasil penelitian Faroid dan Murtadlo (2014) dan Khayer (2014).

Berdasarkan hasil penelitian di atas maka hipotesis yang diajukan adalah

H1 : Corporate Social Responsibilty (CSR) berpengaruh positif dan signifikan terhadap Corporate imagePT. Pegadaian (pesero) di Pulau Lombok

\subsubsection{Pengaruh Corporate image terhadap Loyalitas pelanggan}

Menurut Morley (2002) pelanggan dipercaya menjadi lebih loyal terhadap perusahaan dengan citra yang baik. Penelitian Falla Ilhami Saputra (2013) mengungkapkan bahwa Corporate imagememiliki pengaruh yang positif terhadap loyalitas pelanggan.Sementara penelitian oleh Fetria Eka Yudiana, Joko Setyono (2016) mengungkapkan peran Corporate image yang sangat penting sebagai mediator untuk pembentukan loyalitas pelanggan. Bhote (1995) berpendapat bahwa citra merupakan suatu sikap yang menimbulkan antusiasme konsumen: nilai, kesukaan, dan loyalitas.

Berdasarkan hasil penelitian di atas maka hipotesis yang diajukan adalah :

H2 : Corporate image berpengaruh positif dan signifikan terhadap loyalitas pelanggan PT. Pegadaian (pesero) di Pulau Lombok.

\subsubsection{Pengaruh CSR terhadap loyalitas pelanggan}

Menurut Dwi Kartini (2009) pelanggan akan bersedia mengeluarkan uang berapapun untuk membeli produk karena mereka sadar akan nilai lebih yang akan didapat dari mengkunsumsinya daripada produk yang sejenis tapi tidak berwawasan CSR. Tangapan pelanggan terhadap aktivitas Corporate social responsibility memiliki pengaruh positif terhadap loyalitas pelanggan. (Seravina, 2008). Penelitian yang dilakukan oleh Mulyana, Dian Ayuk Wulansari (2013) menyatakan bahwa CSR memiliki pengaruh positif dan signifikan terhadap reputasi perusahaan. Hasil penelitian yang sama juga ditunjukkan oleh hasil penelitian Syahriah Sari, Abd. Rahman Kadir dan Idayanti (2010) yangmenyatakan bahwa dimensi dimensi CSR memiliki pengaruh positif dan signifikan terhadap loyalitas pelanggan.

Berdasarkan hasil penelitian di atas maka hipotesis yang diajukan adalah

H3 : Corporate Social Responsibilty (CSR) berpengaruh positif dan signifikan terhadap loyalitas pelangganPT. Pegadaian (pesero) di Pulau Lombok.

\subsubsection{Pengaruh CSR terhadap Loyalitas pelanggan melalui Corporate image}

Reward yang bisa di peroleh perusahaan sebagai dampak dari pola kemitraan CSR antara lain: program lebih tepat sasaran dan lebih terorganisasi dalam pelaksanaannya. Pada giliranya perusahaan mendapatkan reputasi yang di harapkan (Dwi Kartini, 2009). Dwi kartini juga menyatakan bahwa target utamanya adalah memperkuat dan memperbanyak pelanggan pelanggan loyal. Preferensi yang sempurna dari pelanggan yang loyal tentang produk berwawasan CSR akan menjadi kekuatan untuk menciptakan pelanggan pelanggan baru. 


\section{NATIONALLY ACCREDITED JOURNAL - DECREE NO. 21/E/KPT/2018}

Di dalam penelitaian Fetria Eka Yudiana, Joko Setyono (2016) dengan judul analisis corporate social responsibility, loyalitas nasabah, Corporate image dan kepuasan nasabah pada perbankan syariah menunjukan penerapan CSR memiliki pengaruh positif namun belum signifikan terhadap loyalitas nasabah, varibel CSR tidak berpengaruh langsung terhadap loyalitas nasabah tanpa dimediasi oleh Corporate image.

Berdasarkan hasil penelitian di atas maka hipotesis yang diajukan adalah

H4 : Corporate Social Responsibilty (CSR) berpengaruh positif dan signifikan terhadap loyalitas pelanggan PT. Pegadaian (pesero) di Pulau Lombok melalui Corporate image.

\section{METODE PENELITIAN}

Jenis penelitian ini adalah penelitian asosiatif dengan pendekatan kuantitatif. Populasi dalam penelitian ini adalah nasabah PT. Pegadaian (Persero) yang pernah menerima bantuan CSR berupa Program Kemitraan di Area Pulau Lombok dalam kurun waktu 3 (tiga) tahun terakhir (2014-2016) yaitu sebanyak 114 orang. Peneliti memilih teknik sampling area atau bisa juga disebut cluster sampling dengan menggunakan rumus slovin maka didapatkan sebanyak 89 orang sampel. Pengujian hipotesis dalam penelitian ini menggunakan model analisis jalur (Path Analysis) untuk menganalisis pola hubungan kausal antar variabel dengan tujuan mengetahui pengaruh langsung dan tidak langsung secara serempak atau mandiri beberapa variabel penyebab terhadap sebuah variabel akibat.

\section{HASIL DAN PEMBAHASAN}

\subsection{Uji Asumsi Klasik}

Berdasarkan pada alat analisis yang digunakan, maka akan dapat dilakukan dengan pertimbangan tidak adanya pelanggaran terhadap asumsi-asumsi klasik, yaitu normalitas, multikolinearitas, autokorelasi dan heteroskedastisitas (Kuncoro, 2007)

\section{a. Uji Normalitas}

Berdasarkan grafik histogram dan grafik normal probabiliti, menunjukkan bahwa model regresi normalitas pengaruh variabel CSR terhadap Corporate image, Corporate image Terhadap Loyalitas Konsumen, CSR Terhadap Loyalitas Konsumen dan pengaruh variabel CSR terhadap Loyalitas Konsumen melalui Corporate image layak dipakai dalam penelitian ini karena memenuhi asumsi normalitas dimana data berdistribusi secara normal dengan sebaran data berada di sekitar garis diagonal.

\section{b. Uji Multikolinieritas}

Dari hasil uji terhadap seluruh variabel menunjukkan bahwa tidak terdapat masalah multikolinearitas antara variable bebas karena nilai tolerance berada di bawah 1 dan nilai VIF jauh di bawah angka 10.

\section{c. Uji Autokorelasi}

Pada tabel Durbin Watson (DW), menunjukan bahwa nilai DW seluruh variabel bernilai diantara -2 sampai +2 , hal ini berarti tidak ada autokorelasi. Dari hasil uji terhadap seluruh variable menunjukkan bahwa data berdistribusi secara normal. 


\section{NATIONALLY ACCREDITED JOURNAL - DECREE NO. 21/E/KPT/2018}

\section{d. Uji Heteroskedastisitas}

Penelitian ini menggunakan grafik Scatterplot yang memberikan gambaran apakah model regresi homoskedastisitas atau heteroskedastisitas. Berdasarkan hasil gambar pada penelitian ini dapat dilihat bahwa titik - titik yang ada tidak membentuk pola yang teratur. Sehingga dapat disimpulkan bahwa pada data dalam penelitian ini tidak terjadi heteroskodesitas. Artinya dalam fungsi regresi dipenelitian ini tidak muncul gangguan karena varian yang tidak sama.

Dari hasil uji terhadap seluruh variable menunjukkan bahwa tidak ada autokorelasi karena nilai DW seluruh variable berada di antara -2 sampai +2 .

\subsection{Uji Hipotesis dan Pembahasan}

Setelah dihitung ulang besarnya kontribusi/ pengaruh variabel independen terhadap variabel dependen, selanjutnya dilakukan uji signifikasi untuk mendapatkan kesimpulan yang lebih eksak dari hasil penelitian.

Dalam uji Hipotesis dapat ditunjukan dengan melihat nilai $\mathrm{t}$ hit dengan $\mathrm{t}$ tabel dan $\mathrm{F}$ hitung dan F tabel dalam SPSS 16.00 seperti yang terlihat pada tabel 4.21 sebagai berikut.

Tabel 5.1 Hasil analisis koefisien korelasi,Sig, thit, Fhit,R, R2, R Adjustment

\begin{tabular}{|l|c|c|c|c|c|c|c|c|c|}
\hline $\begin{array}{c}\text { Variabe } \\
\mathrm{l}\end{array}$ & $\begin{array}{c}\text { Korelas } \\
\mathrm{i}\end{array}$ & $\mathrm{R}$ & $\begin{array}{c}\text { Koefisie } \\
\mathrm{n} \text { Beta }\end{array}$ & $\mathrm{R}^{2}$ & $\mathrm{t}$ hit & $\begin{array}{c}\mathrm{P} \\
\text { valu } \\
\mathrm{e}\end{array}$ & $\mathrm{F}$ hit & $\begin{array}{c}\mathrm{R}^{2} \\
\text { Adjust }\end{array}$ & $\begin{array}{c}\text { Kesimpula } \\
\mathrm{n}\end{array}$ \\
\hline $\mathrm{X}_{1 \rightarrow \mathrm{X}}$ & 0.853 & $\begin{array}{c}0.85 \\
3\end{array}$ & 0.653 & $\begin{array}{c}0.72 \\
7\end{array}$ & 15.215 & 0.000 & $\begin{array}{c}231.50 \\
3\end{array}$ & $\begin{array}{c}0.72 \\
4\end{array}$ & Signifikan \\
$\mathrm{X}_{2 \rightarrow \mathrm{Y}}$ & 0.875 & $\begin{array}{c}0.87 \\
5\end{array}$ & 0.675 & $\begin{array}{c}0.76 \\
6\end{array}$ & 16.896 & 0.000 & $\begin{array}{c}285.47 \\
1\end{array}$ & $\begin{array}{c}0.76 \\
4\end{array}$ & Signifikan \\
$\mathrm{X}_{1 \rightarrow \mathrm{Y}}$ & 0.931 & $\begin{array}{c}0.93 \\
1\end{array}$ & 0.731 & $\begin{array}{c}0.86 \\
6\end{array}$ & 23.699 & 0.000 & $\begin{array}{c}561.64 \\
6\end{array}$ & $\begin{array}{c}0.86 \\
4\end{array}$ & Signifikan \\
$\mathrm{X}_{1 \rightarrow \mathrm{Y}}$ & 0.875 & 0.94 & 0.301 & 0.89 & 4.406 & 0.000 & 349.95 & 0.88 & Signifikan \\
$\mathrm{X}_{2}$ & 0.932 & 4 & 0.674 & 1 & 9.878 & 0.000 & 4 & 8 & \\
\hline
\end{tabular}

\subsubsection{Pengaruh CSR terhadap Corporate Image}

Hipotesis pertama yang diuji adalah pengaruh CSR terhadap Corporate Image. Berdasarkan Tabel 5.1 didapatkan nilai probabilitas ( $p$-value) pengaruh CSR terhadap Corporate Image sebesar 0,000 sedangkan nilai significance level $0.05(\alpha=5 \%)$. Ini menunjukkan bahwa nilai probabilitas ( $p$-value) lebih kecil dari significance level $0.05(\mathrm{a}=5 \%)$ atau (prob $<0.05)$, maka Ho ditolak dan Ha diterima. Ini menunjukkan bahwa CSR memiliki pengaruh langsung, positif dan signifikan terhadap Corporate Image. Sehingga dapat disimpulkan bahwa hipotesis ke-1 pada penelitian ini dapat didukung atau diterima. Besarnya nilai pengaruh langsung CSR terhadap Corporate Image adalah 0,653 atau sebesar 42,64\%. Ini menunjukkan bahwa kedua variabel ini saling terkait dan berjalan searah. Artinya, jika program kemitraan dengan pelanggan dilakukan oleh PT. Pegadaian (persero) secara terus menerus maka akan berdampak pada meningkatnya citra dan performa perusahaan yang semakin baik. Sehingga akan berdampak pula pada PT. Pegadaian (persero) yang semakin dikenal oleh masyarakat di pulau Lombok. 


\section{NATIONALLY ACCREDITED JOURNAL - DECREE NO. 21/E/KPT/2018}

\subsubsection{Pengaruh Corporate Image terhadap Loyalitas Pelanggan}

Hipotesis kedua yang diuji adalah pengaruh Corporate Image terhadap loyalitas pelanggan. Berdasarkan Tabel 4.21 didapatkan nilai probabilitas ( $p$-value) pengaruh Corporate Image terhadap loyalitas pelanggan sebesar 0,000 sedangkan nilai significance level 0.05 ( $\alpha=5 \%)$. Ini menunjukkan bahwa nilai probabilitas ( $p$-value) lebih kecil dari significance level 0.05 ( $\alpha=5 \%$ ) atau (prob < 0.05), maka Ho ditolak dan Ha diterima, artinya Corporate Image berpengaruh positif dan signifikan terhadap loyalitas pelanggan. Ini menunjukkan bahwa Corporate Image memiliki pengaruh langsung, positif dan signifikan terhadap loyalitas pelanggan. Sehingga dapat disimpulkan bahwa hipotesis ke-2 pada penelitian ini dapat didukung atau diterima. Besarnya nilai pengaruh langsung Corporate Image terhadap loyalitas pelanggan adalah 0,675 atau sebesar 45,56\%. Ini menunjukkan bahwa kedua variabel ini saling terkait dan berjalan searah. Artinya, jika PT. Pegadaian (persero) terus melaksanakan program kemitraan dengan pelanggan yang berada di pulau Lombok dengan cara memperkenalkan slogan, produkproduk, memberikan kepedulian terhadap pelanggan serta pemberian pelayanan yang baik kepada para pelanggan maka akan berdampak pada loyalitas pelanggan yang semakin tinggi.

\subsubsection{Pengaruh CSR terhadap Loyalitas Pelanggan}

Hipotesis ketiga yang diuji adalah pengaruh CSR terhadap loyalitas pelanggan. Berdasarkan Tabel 4.21 didapatkan nilai probabilitas ( $p$-value) pengaruh CSR terhadap loyalitas pelanggan sebesar 0,000 sedangkan nilai significance level $0.05 \quad(\alpha=5 \%)$. Ini menunjukkan bahwa nilai probabilitas ( $p$-value) lebih kecil dari significance level 0.05 ( $\alpha=5 \%)$ atau (prob < 0.05), maka Ho ditolak dan Ha diterima. Ini menunjukkan bahwa CSR memiliki pengaruh langsung, positif dan signifikan terhadap loyalitas pelanggan. Sehingga dapat disimpulkan bahwa hipotesis ke-3 pada penelitian ini dapat didukung atau diterima. Besarnya nilai pengaruh langsung CSR terhadap loyalitas pelanggan adalah 0,731 atau sebesar 53,43\%. Artinya, jika program CSR yang dilakukan oleh PT. Pegadaian (persero) terus dijalankan dengan baik, maka akan berdampak pada lebih dikenalnya PT. Pegadaian (persero) oleh masyarakat di pulau Lombok, dan program kemitraan tersebut akan mampu membuat pelanggan terus menggunakan produk dan jasa yang ditawarkan oleh PT. Pegadaian (persero), sehingga pada akhirnya membuat pelanggan menjadi loyal terhadap PT. Pegadaian (persero).

\subsubsection{Pengaruh CSR terhadap Loyalitas Pelanggan melalui Corporate Image}

Hipotesis keempat yang diuji adalah pengaruh CSR terhadap loyalitas pelanggan melalui Corporate Image. Berdasarkan Tabel 4.21 didapatkan nilai probabilitas ( $p$-value) pengaruh CSR terhadap Corporate Image sebesar 0,000 sedangkan nilai significance level 0.05 $(\alpha=5 \%)$. Ini menunjukkan bahwa nilai probabilitas ( $p$-value) lebih kecil dari significance level 0.05 $(\alpha=5 \%)$ atau ( prob < 0.05), maka Ho ditolak dan Ha diterima. Ini menunjukkan bahwa CSR memiliki pengaruh langsung, positif dan signifikan terhadap loyalitas pelanggan melalui Corporate Image. Sehingga dapat disimpulkan bahwa hipotesis ke-4 pada penelitian ini dapat didukung atau diterima.

Ini menunjukkan bahwa variabel CSR saling terkait dan berjalan searah dengan loyalitas pelanggan melalui Corporate Image. Artinya, jika program kemitraan yang dilakukan oleh PT. Pegadaian (persero) dijalankan secara berkelanjutan, berdampak pada lebih dikenalnya berbagai produk dan jasa yang dimiliki PT. Pegadaian (persero), hal ini akan membuat pelanggan terus menggunakan produk dan jasa yang ditawarkan tersebut dan pada akhirnya membuat pelanggan terus menggunakannya. Berdasarkan hasil observasi peneliti didapatkan 


\section{NATIONALLY ACCREDITED JOURNAL - DECREE NO. 21/E/KPT/2018}

bahwa sebagian pelanggan tetap setia dengan produk PT. Pegadaian meskipun ada informasi negatif atau munculnya pesaing lain.

\section{KESIMPULAN}

Penilaian responden terhadap corporate image pada PT. Pegadaian (persero) secara umum dapat dikatakan baik. PT. Pegadaian (persero) diharapkan terus meningkatkan citra yang dimiliki dengan terus mengontrol serta bertanggung jawab pada program kemitraan yang telah dilakukan. Disamping itu, penyebaran pelaksanaan program kemitraan di nilai belum merata, PT pegadaian (persero) harus dapat memanfaatkan dengan maksimal setiap unit unit kerja (UPC) yang tersebar di pulau Lombok untuk meningkatkan sebaran pelaksanaan program kemitraan dengan lebih memperhatikan lingkungan sekitar. Kebutuhan masyarakat di tiap wilayah tentu berbeda, penyesuaian kebijakan untuk memenuhi kebutuhan masyarakat mutlak di butuhkan, misalnya kebijakan untuk mengakomodir kebutuhan masyarakat pesisir yang berprofesi sebagai nelayan yang tidak memenuhi beberapa kriteria sebagai penerima program kemitraan. Selain itu diharapkan karyawan PT. Pegadaian (persero) memberikan respon cepat terhadap keluhan mitra.

Kedepan diharapkan agar penelitian serupa dapat memperluas cakupan penelitian terkait CSR maupun Corporate Image dengan menambahkan variabel-variabel lain. Diharapkan kepada peneliti-peneliti selanjutnya untuk dapat memperluas dan mengkaji secara lebih lanjut terkait variabel CSR dan Corporate Image. Kemudian mempertimbangkan atau menambah variabel yang dapat mempengaruhi loyalitas pelanggan seperti: kepuasan pelanggan, atribut produk atau bauran pemasaran. Jika perlu penelitian yang selanjutnya agar menambah jumlah kuesioner yang disebarkan sehingga data yang didapat lebih banyak untuk diteliti. Termasuk mengambil sampel responden dibeberapa beberapa perusahaan yang memiliki produk sama dengan Pegadaian, sehingga diperoleh hasil perbandingan terkait pengaruh CSR dan Corporate Image terhadap Loyalitas Nasabah.

\section{DAFTAR PUSTAKA}

Anggoro, Linggar, 2005. Teori dan Profesi Kehumasan Serta Aplikasinya di Indonesia. Penerbit PT. Bumi Aksara, Jakarta.

Arikunto, Suharsimi. 2013. Prosedur Penelitian Suatu Pendekatan Praktik. Jakarta: Rineka Cipta.

Basuki Sri Rahayu, Endang Saryanti (2014). "pengaruh kualitas pelayanan, hubungan pelanggan dan citra perusahaan terhadap loyalitas melalui kepuasan nasabah"

Bhote, K. R. 1996. Beyond customer satisfaction to customer loyalty: the key to greater Profitabilitu. AMACOM. New York

Brown, T. J. and Dacin, P. A. (1997). The Company and the Product: Corporate Associations and Consumer Product Responses. Journal of Marketing

Lois A. Mohr, Deborah J. Webb, And Katherme E. Harris, (2009). "A re-examination of socially responsible consumption and its measurementJournal of Business Research", vol. 61

Dharmesta dalam Diah Dharmayanti (2006). Jurnal: Analisis Dampak Service Performance dan Kepuasan Sebagai Moderating Variable Terhadap Loyalitas Nasabah (Studi Pada Nasabah Tabungan Bank Mandiri Cabang Surabaya), Jurnal Manajemen Pemasaran, Vol.1, No. 1 


\section{NATIONALLY ACCREDITED JOURNAL - DECREE NO. 21/E/KPT/2018}

Falla Ilhami Saputra (2013). "kualitas layanan, citra dan pengaruhnya terhadap loyalitas melalui kepuasan pelanggan (studi pada PT Bank BNI 46 sentra kredit kecil Surabaya)".

Faroid dan Murtadlo (2014). "pengaruh penerapan corporate social responsibility terhadap citra perusahaan PT Tirta Investama Kebon candi pada masyarakat desa Jeladri Winongan Pasuruan".

Fitria Eka Yudiana, Joko Setyono (2016). "analisis corporate social responsibility, loyalitas nasabah, Corporate image dan kepuasan nasabah pada perbankan Syariah".

Ghozali (2005) Aplikasi Analisis Multivariate dengan Program SPSS. Semarang: Badan Penerbit Universitas Diponegoro.

Gremler and Brown. (1997). Customer Relationship Marketing: A Strategic Imperative in the World of e.Business. John Wiley and Sons Ltd. Canada.

Griffin (2003). Customer Loyalty. Edisi Revisi dan Terbaru. Terjemahan oleh Dwi Kartini Yahya. 2005. Jakarta: Erlangga.

Hadi, Nor. (2011). Corporate Social Responsibility. Yogyakarta: Graha Ilmu

Hurriyati dan Sofyani (2010), "pengaruh corporate social responsibility terhadap Corporate image PT Bank Negara Indonesia"

Howard, J.A. (1994). Buyer behavior in marketing strategy (second edition). New Jersey, Prentice Hall.

Jay Kandampully dan Dwi Suhartanto. (2000). Customer loyalty in the hotel industry: the role of customer satisfaction and image. International Journal of Contemporary Hospitality Management Volume 12 Number 62000

Kartini, Prof. Dr. Dwi, (2009). Corporate Social Responsibility Transformasi Konsep Sustainability Management dan implementasi Di Indonesia, PT. RefikaAditama, Bandung.

Kasali, Rhenald. 2005. Manajemen Public Relations Konsep dan Aplikasinya di Indonesia. PT Pustaka Utama Grafiti.Jakarta

Ki-Han Chung, Ji-Eun Yu, Myeong-Guk Choi, and Jae-Ik Shin (2015). "the effects of Csron customer satisfaction and loyalty in china: the moderating role of corporate"

Kotler dan Lee, (2005), Corporate Social Responsibility; Doing the Most Good for Your Company and Your Cause. New Jersey: John Wiley ESons, Inc.

Kotler, Philip dan Kevin Keller. (2009). Manajemen Pemasaran. Jilid 1. Edisike 13. Diterjemahkan oleh Bob Sabran. Jakarta: Erlangga.

Kotler \& Keller (2006). Marketing Management, twelfth edition, New Jersey: Pearson Education, In

Muhadjir dan Qurani (2011), "pengaruh penerapan corporate social responsibility terhadap persepsi nasabah bank dan dampaknya terhadap Corporate image"

Mulyana, Dian Ayuk Wulansari (2013). "implementasi corporate social responsibility (CSR) sebagai pembentuk citra perusahaan dan loyalitas"

Morley, M. (2002). How to Manage Your Global Reputation, 2nd ed. New York: New York University Press.

Navickas, V., \&Kontautiene, R. (2011). Influence of Corporate Philanthropy on Economic Performance. Verslas: teorijairpraktika - Business: Theory and Practice.

Nirmalasari dan Ulum (2014). “corporate social responsibility :respon public dan dampaknya pada Corporate image yang menunjukkan bahwa corporate social responsibility yang dilakukan oleh PLN Cabang Bandung dalam bidang lingkungan, kesehatan, dan pendidikan"

Riduwan, Kuncoro, Engkos Achmad. (2007). Cara Menggunakan dan MemaknaiAnalisisJalur (Path Analysis). Bandung: Alfabeta. 
NATIONALLY ACCREDITED JOURNAL - DECREE NO. 21/E/KPT/2018

Sethyon Ketut, (2002). Menapak Ke Masa Depan dengan Kegigihan Masa Lalu Dalam Pegadaian Seratus tahun, edisi pertama. Jakarta: Penerbit Perum Pegadaian Kantor Pusat.

Sekaran, (2006). Research Methods for Business (Metodologi Penelitian untuk Bisnis). Jakarta: Salaemba Empat

Sen dan Bhattacharya (2001). Doing Better at Doing Good: When, Why and How Consumers Respond to Corporate Social Initiatives. California Management Review. Vol. 47, No. 1.

Seravina, (2008), Pengaruh Penerapan Corporate Social Responsibility (CSR) terhadap Loyalitas Nasabah Tabungan BRItama (StudiKasus pada Nasabah PT Bank Rakyat Indonesia (Persero) Tbk. Cabang Bogor)

Sugiyono, (2004). Metodologi Penelitian Administrasi, Penerbit Alfabeta, Bandung

Sugiyono, (2013). Metode Penelitian kuantitatif, kualitatif, $R$ dan D. Bandung:Penerbit Alfabeta

Sugiyono, (2009). Metode Penelitian Pendidikan. Bandung: CV. Alfabeta

Syahriah Sari, Abd. Rahman Kadir dan Idayanti (2010). "judulpengaruhcorporate social responsibility (CSR) terhadap loyalitas nasabah pada PT. Bank Danamon Indonesia, tbk Makassar"

Undang- Undang Republik Indonesia Nomor 40 Tahun 2007 tentang Perseroan Terbatas Pasal 74

Yaskun dan Cahyono (2016). "pengaruh implementasi corporate social responsibility (CSR) terhadap citra perusahaan (studi pada PT. Semen Indonesia (Persero), Tbk)"

Yusdantara dan Rahanatha (2015). "pengaruh corporate social responsibility terhadap reputasi perusahaan yang dimediasi oleh kepuasan pelanggan (studi pada PT. Coca-Cola Amatil Denpasar)"

Zeithaml dkk. (1996). Service Marketing. Singapore: Mc 